\title{
Estudo da Expressão Criativa da Criança e do Adolescente com Câncer em Casas de Apoio
}

\author{
A Study on the creative expression of children with cancer at \\ assistance homes
}

\author{
Maria Carmen Batista Bahia*
}

Resumo

\begin{abstract}
A partir da premissa de que "expressão" e o modo de manifestação e configuração, com ajuda instrumental, de sentimentos, de ações ou pensamentos, buscamos neste estudo, entender como o trabalho expressivo, com recursos artísticos, vem estabelecer um ponto de apoio no atendimento mais integral da criança e do adolescente com câncer, estimulando a continuidade de seu processo natural de desenvolvimento. Estabelecemos que as qualidades expressivas são seus meios de comunicação, prendem sua atenção, possibilitam o entendimento e a interpretação das experiências, bem como determinam os padrões formais por eles criados. A inserção da prática criativa, sob essas condições, pressupõe um encadeamento de atividades com a intenção de obter um resultado minimamente eficaz. Este estudo não visa a soluções, mas ao acompanhamento da experiência criativa com linguagens artísticas, escolhidas de acordo com a problemática da criança doente. $\mathrm{O}$ instrumento central da pesquisa foi um ateliê de arte - a oficina criativa - que serviu diretamente a grupos de crianças e adolescentes carentes e com câncer, que se encontravam hospedados em casas assistenciais de apoio localizadas na região de São Paulo. Seguimos algumas experimentações de campo, de onde obtivemos vários caminhos possíveis para a expressão gerada por recursos artísticos e de linguagem. Procuramos colher, em cada exemplo, aspectos dessa expressão e seus diferentes modos de manifestação no desenho, pintura, colagem e linguagem verbal. A idéia foi estruturar o trabalho, entrecruzando questões levantadas pela arte-educação e arte-terapia, explorando os diferentes aspectos, conceituais e concretos, que norteiam as alternativas metodológicas da prática criativa. Propomos, por fim, uma análise compreensiva, considerando os aspectos operacionais e motivadores do processo de criação encontrados nos recursos artísticos. Ao tentar entender as contribuições potenciais dos recursos artisticos no espaço do câncer infantil, buscamos considerar como a relação entre processo criativo e processo terapêutico pode ajudar a criança a melhorar sua qualidade de vida, no sentido mais lúdico de viver, apesar da doença.
\end{abstract}

\begin{abstract}
Abstrat
Based on the premise that the "expression" is used for the manifestation and configuration of a person, with the instrumental help of disclosing feelings, actions or thoughts, we intend to understand how the expressive work that uses artistic resources is established as a support for the integral care of children and adolescents with cancer, stimulating the continuity of their natural process of development. It is established that the expressive qualities are their means of communication, they hold their attention, enable the understanding and interpretation of experiences as well as determine the formal patterns created by them.
\end{abstract}


The introduction of the creative practice under these conditions, presupposes a series of activities with the purpose of obtaining a minimally efficient result. The purpose of this study is not to find the solutions, but it is to follow the creative experience closely, especially those chosen according to the sick child's problematic issue.

The main research instrument was the creative workshop, which served directly to groups of children and adolescents with cancer that were housed at assistance homes in the region of São Paulo. Some field experimentations were followed, from which several possible ways for understanding the expression conveyed by artistic and language resources, were revealed. In each example, we tried to grasp aspects of this expression and their different ways of showing it through drawings, paintings, pasting and verbal language.
The idea was to organize the work, crosschecking the questions raised by art-education and art-therapy, exploring the different conceptual and concrete aspects that direct the methodological alternatives of the creative practice. At last, it is proposed a comprehensive analysis, taking into consideration the operational and motivational aspects of the creation process found in the artistic resources.

As we try to understand the potential contributions of the artistic resources in the space of the childhood cancer, we believe it is important to consider how the relation between creative process and therapeutic process can help the child to improve his/her quality of life in a more ludicrous way of living, despite the disease. 